\title{
Smart Connector Helmet \& Automatic GPS \\ Inovasi Alat Bantu Komunikasi antar Pengemudi dan Penunjuk Arah Berbasis Internet
}

\author{
Nur Hasanah ${ }^{1)}$, Yuda Prasetya Anggara ${ }^{2)}$, Ramadhani Hary Hidayati ${ }^{3)}$, M Riyantoro ${ }^{4)}$, Mohammad \\ Agung Syahroni ${ }^{5}$, Wahid Ansor Aditya ${ }^{6)}$ \\ Pendidikan Teknik Informatika Universitas Negeri Yogyakarta \\ 1) nurhasanah@uny.ac.id
}

\begin{abstract}
ABSTRAK
Perancangan smart connector helm dan automatic GPS bertujuan untuk membantu komunikasi antar pengemudi dan sebagai penunjuk arah yang berbasis internet. Alat bantu komunikasi ini terpasang di helm dan terkoneksi dengan smartphone. User dapat berkomunikasi antar Helm dengan Helm yang lain melalui jaringan wireless sinyal radio dari HT. Helm juga terhubung pada smartphone menggunakan bluetooth. Smartphone berfungsi sebagai penunjuk arah dengan adanya GPS dan aplikasi pendukung yang dibuat. Selain itu, pengemudi juga dapat menerima telfon dan mendengarkan musik dengan helm tanpa harus memegang smartphone. Metode perancangan menggunakan pendekatan water fall. Hasil rancangan diperoleh: (a) kerangka Helm yang digabungkan dengan headset, bluetooth, HT; (2) Rancangan aplikasi dari smartphone yang terhubung dengan helm.
\end{abstract}

Kata kunci: Helm, GPS, Smart connector, bluetooth, smartphone, komunikasi

\section{PENDAHULUAN}

Dari tahun ketahun, impor sepeda motor di Indonesia semakain meningkat. Hal ini disebabkan karena permintaan konsumen lebih memilih kendaraan pribadi yang efisien, siap digunakan kapan saja tanpa perlu menunggu sekian menit hanya untuk melakukan perjalanan ke tempat kerja atau pun tempat - tempat lainnya. Berbeda dengan kendaraan umum yang setiap kali ingin bepergian harus menunggu angkutan datang. Banyak faktor kenapa konsumen lebih memilih kendaraan motor pribadi ketimbang kendaraan mobil pribadi. Selain dapat selap selip dikemacetan, juga efisien terhadap waktu.

Akibat dari banyaknya pengendara sepeda motor, muncullah masalah baru, yaitu kecelakaan. Salah satu faktornya adalah mengangkat telepon disaat berkendara. Lalu kenapa mengangkat telepon disaat berkendara dapat menyebabkan kecelakaan? Karena, pada saat berkendara dibutuhkan kosentrasi yang ekstra. Dengan melakukan aktifitas saat berkendara dapat memecah konsentrasi. Contohnya adalah mengangkat telepon. Dari permasalahan ini, munculah sebuah ide "Smart Connector Helmet \& Automatic GPS".

Republika.co.id, Washington - American

Automobil Association

mengungkapkan bahwa penyebab kecelakaan akibat gangguan penggunaan ponsel, bersolek, dan berjoget di dalam mobil lebih besar daripada yang diperkirakan sebelumnya. Dan kecelakaan karena penggunaan ponsel ini sebesar 58\%. Dari data di atas, tentunya dirasa perlu solusi untuk mengatasi penggunaan ponsel ketika dijalan, khususnya untuk pengendara motor yang juga harus wajib memakai helm sebagai keamanan.

Telekomunikasi nirkabel adalah transfer informasi antara dua titik atau lebih titik yang tidak terhubung oleh ( penghantar listrik ). Berbaga perangkat yang mendukung wireless adalah radio, mobile, portable radio 2 arah, telepon seluler, dan PDA. Untuk saling mengingatkan maupun sebagai sarana komunikasi pada waktu-waktu tertentu, tentu kita tidak lepas dengan gadget maupun alat elektronik, agar tidak ribet atau susah dalam penggunaannya, penggabungan alat komunikasi ke dalam helm dengan perantara wireless sangat diperlukann. 
GPS navigasi digunakan untuk penunjuk arah atau sebagai alat navigasi mencari suatu lokasi. GPS ini mendeteksi lokasi tiap detik dengan mengandalkan sinyal dari satelit. Dengan canggih pun banyak layanan yang sekaligus menyajikan mapnya dan layanan audio GPS untuk pemandu perjalan kita ke suatu lokasi yang nantinya dipadukan kedalam helm.

Untuk GPS tracker sendiri berfungsi untuk menyimpan lokasi kita ketika kita dalam keadaan tersesat maupun tidak mengetahui keberadaan kita, sehingga orang terdekat / orang lain bisa tahu posisi kita dengan mengecek smartphone ataupun komputer mereka.

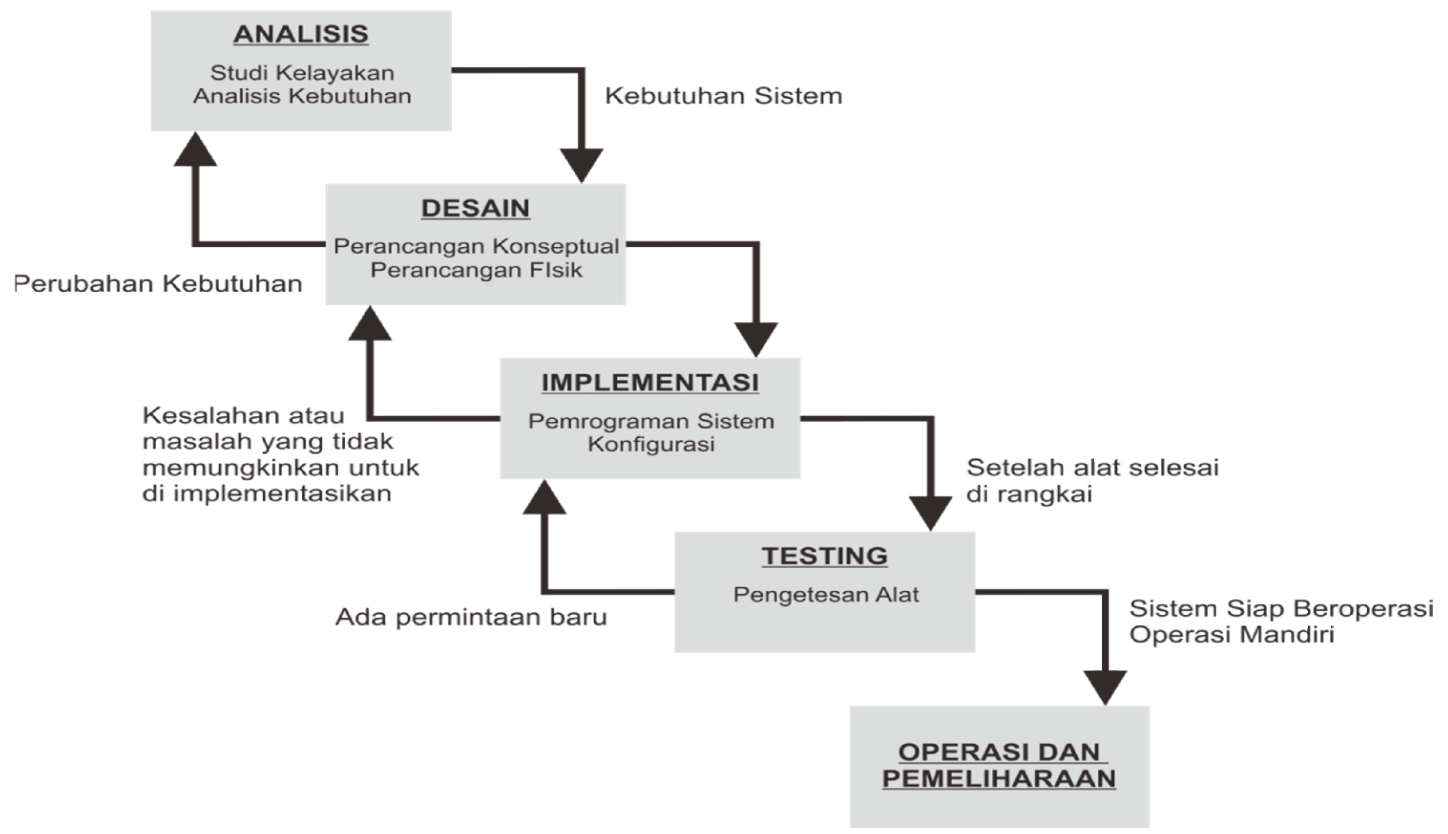

Gambar 1. Langkah Pengembangan

Pada tahap analisis kebutuhan ini dilakukan observasi dan wawancara terhadap pihak-pihak yang terkait seperti pengendara motor, masyarakat, orang-orang yang pernah touring dan melihat potensi dari pengembangan helm ini. Langkah berikutnya yaitu membuat rancangan desain sesuai dengan spesifikasi dan harapan. Meliputi rancangan fisik dan rancangan secara konseptual. Langkah ketiga adalah implementasi yang mencakup menciptakan kerangka, coding dan perakitan secara utuh. Kerangka helm

\section{METODE}

Pengembangan perangkat lunak yang digunakan dalam penelitian ini menggunakan model water fall yang dikembangkan Davis, Bershoff, dan Comer, (1988:1453); Jalote (2008); Pressman (2015:41-42). Pemilihan model water fall dilandasi pemikiran bahwa secara teknis pengembangan perangkat lunak ini terstruktur, terdokumentasi dengan rinci dan lengkap sehingga memudahkan dalam proses pemeliharaan. sebagai berikut:

Langkah-langkah metodenya adalah Setelah alat selesai Sistem Siap Beroperasi Operasi Mandiri 
tahap perawatan dimana produk yang sudah diciptakan atau di kembangkan dilakukan perawatan.

Pengembangan ini dilakukan di jurusan pendidikan teknik elektronika FT UNY.

\section{HASIL DAN PEMBAHASAN}

Rancang Bangun instrumen / peralatan inovasi alat bantu komunikasi antar pengemudi dan penunjuk arah berbasis internet adalah sebagai berikut ini :

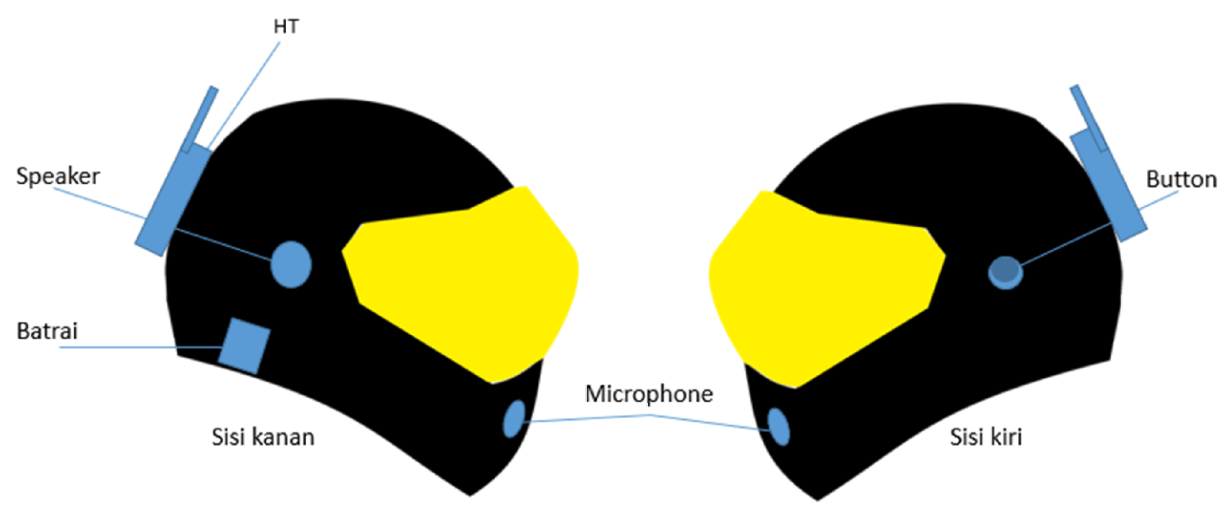

Gambar 2. Desain Bangun Instrumen/Peralatan

Pada sisi kanan bagian luar helm terdapat HT yang berfungsi untuk berkomunikasi dengan pengendara lainnya. Selain itu terdapat speaker dan baterai yang letaknya di dalam helm. Pada sisi kiri bagian luar helm terdapat button yang berfungsi untuk komunikasi antar pengemudi. Jika pengemudi ingin berbicara, maka button ini harus selalu ditekan selama berbicara. Pada sis depan bagian dalam helm terdapat microphone.

Sedangkan desain sistem inovasi alat bantu komunikasi antar pengemudi dan penunjuk arah berbasis Internet adalah sebagai berikut ini:

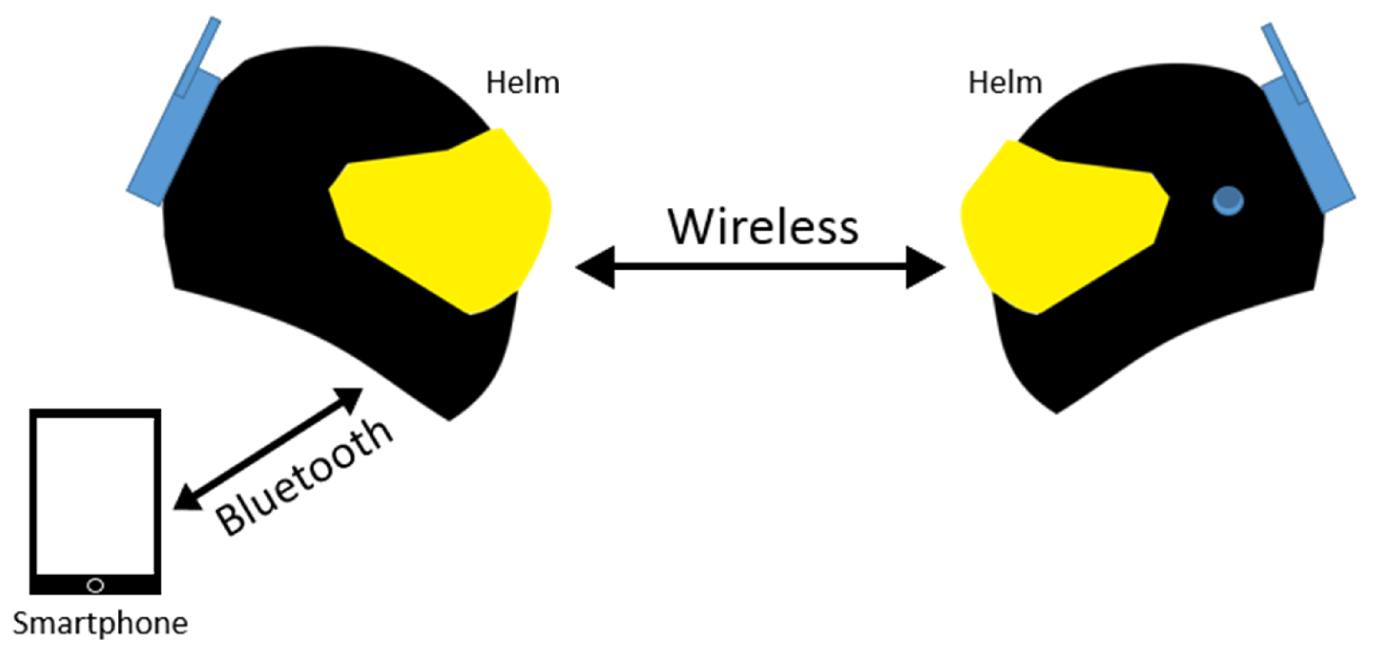

Gambar 3. Desain Sistem 
User dapat berkomunikasi antar Helm dengan Helm yang lain melalui jaringan wireless sinyal radio dari HT. Helm juga terkoneksi dengan smartphone melalui bluetooth. Smartphone berfungsi sebagai penunjuk arah dengan adanya GPS dan aplikasi pendukung yang dibuat. Selain fasilitas GPS, terdapat pula aplikasi lainnya di smartphone yang dapat dimanfaatkan oleh pengemudi. Berikut ini adalah gambaran teknologi yang dikembangkan:
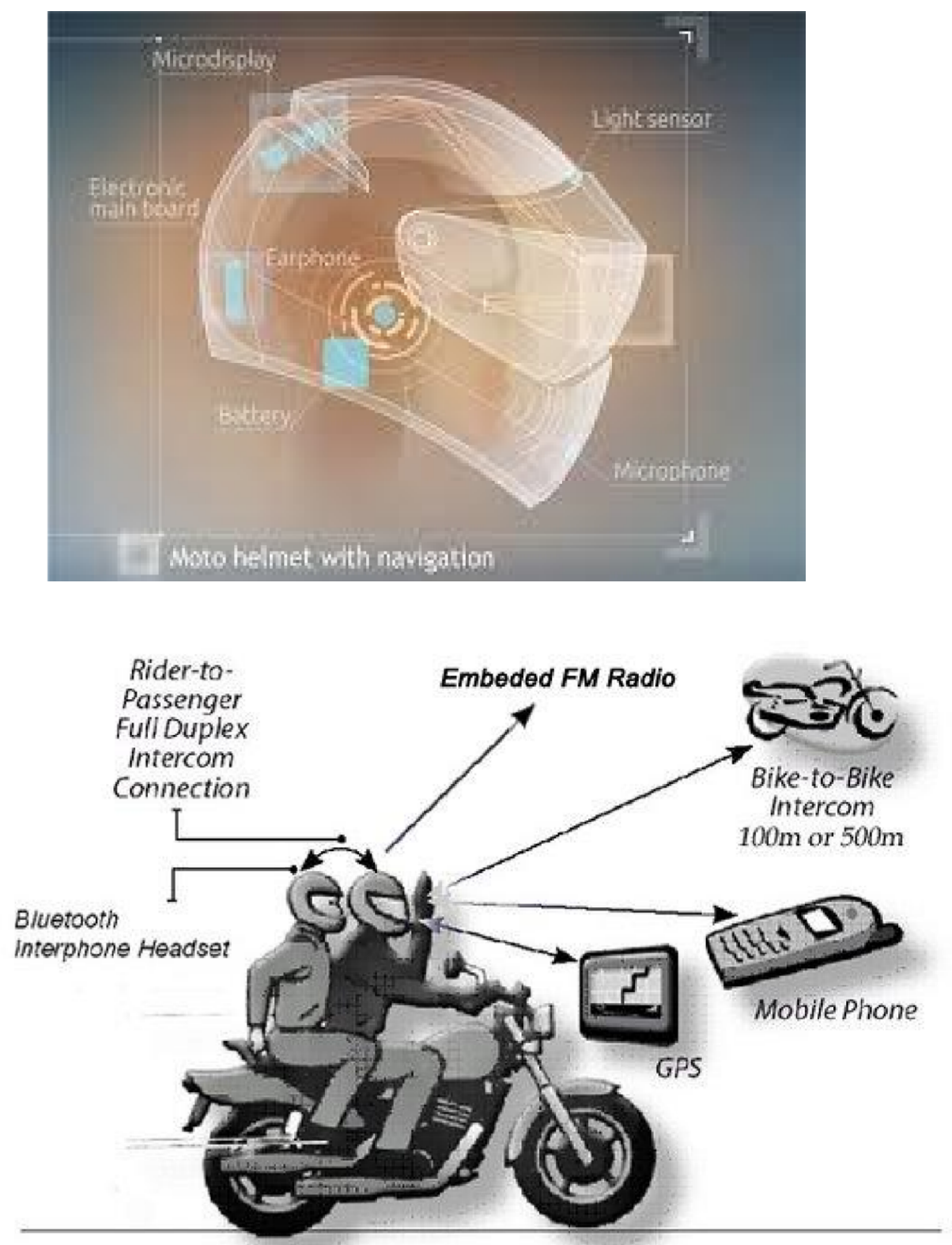

Gambar 4. Kerja Helm GPS dan desain helm

Inovasi alat bantu komunikasi antar pengemudi di desain dalam helm yang terpasang di dalam dan di luar di helm. Pada helm tersebut terpasang HT, speaker, charger, baterai, microphone, dan tombol yang digunakan pada saat pengemudi ingin berkomunikasi. Pada saat pengemudi ingin berkomunikasi dengan pengemudi yang lainnya, pengemudi menekan tombol switch yang bekerja seperti HT, sehingga pengemudi harus menekan tombol tersebut secara terus menerus pada saat berbicara. Selanjutnya 
pembicaraan tersebut akan dikirim oleh pengemudi yang lainya. Selain tombol tersebut, ada satu tombol switch yang berfungsi untuk koneksi dengan smartphone. HP tersebut terkoneksi menggunakan bluetooth. Dengan terkoneksinya smartphone dan helm tersebut, pengemudi mempunyai kelebihan yaitu dapat mencari lokasi, menerima panggilan telepon dan mendengarkan musik.

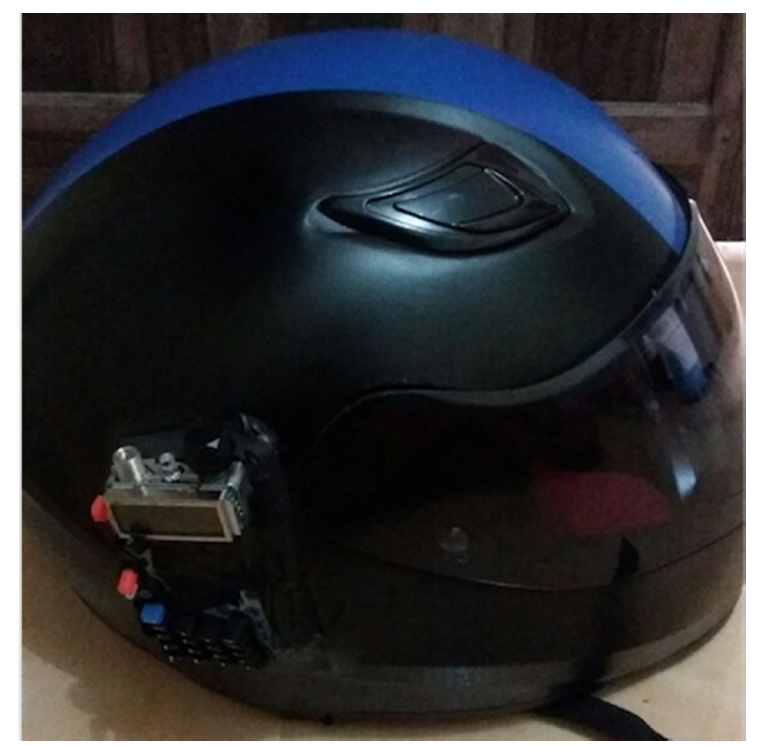

Gambar 5. Smart Connector Helm dan Automatic GPS

Selain itu, smartphone juga mempunyai fasilitas navigasi GPS yang dapat digunakan sebagai penunjuk arah atau sebagai alat navigasi mencari suatu lokasi. Fasilitas ini dapat menyajikan mapnya dan layanan audio GPS untuk pemandu perjalan kita ke suatu lokasi yang dipadukan kedalam helm. Hal ini dapat mengurangi resiko kecelakaan karena pengemudi tidak perlu membuka smartphone untuk melihat map, tetapi cukup mendengarkan suara navigasi yang telah terkoneksi di dalam helm.

\section{SIMPULAN}

Inovasi alat bantu komunikasi antar pengemudi ini dikembangkan dan didesain pada helm. User dapat berkomunikasi antar Helm dengan Helm yang lain melalui jaringan wireless sinyal radio dari HT. Smartphone berfungsi sebagai penunjuk arah dengan adanya GPS dan aplikasi pendukung yang dibuat. GPS navigasi digunakan untuk penunjuk arah atau sebagai alat navigasi mencari suatu lokasi. GPS ini mendeteksi lokasi tiap detik dengan mengandalkan sinyal dari satelit.

\section{DAFTAR RUJUKAN}

Davis, Alan N. Bershoff, Edward H. \& Comer, Edward R. (1988). A Strategy for comparing alternative software development life cycle models. IEEE Transactions on Software Engineering, Vol. 14, No. 10, October 1988. Page(s): $1453-1461$.

Jalote, Pankaj. (2008). A Concise introduction to software engineering. London: Springer-Verlag

Letham, Lawrence. (2008). GPS Made Easy: Using Global Positioning Systems in the Outdoors. Washington : Mountaineers Books.

Pressman, Roger S. \& Maxim, Bruce R. (2015). Software Engineering, A practitionare's approach, $8^{\text {th }}$ edition. New York: Mc Graw-Hill Education

Terry, Karen Steede (2000). Integrating GIS and the Global Positioning System. California : Esri Press. 